\title{
Synthesis of Glutamic Acid-based Dendritic Helical Poly(phenylacetylene)s
}

\author{
By Yanming HU, Ruiyuan LIU, Fumio SANDA, ${ }^{*}$ and Toshio MASUDA ${ }^{*}$
}

L-Glutamic acid-based novel dendritic phenylacetylene derivatives $\mathbf{1}$ and $\mathbf{2}$ were synthesized and polymerized with a rhodium catalyst to afford the corresponding polymers [poly(1) and poly(2)] with high molecular weights in 83-95\% yields. Poly(1) formed a helical structure with predominantly one-handed screw sense in DMF, $\mathrm{CHCl}_{3}$, and $\mathrm{MeOH}$, and poly(2) did in DMF. The helical conformation of poly(1) and poly(2) could be tuned by temperature. Poly(1) underwent solvent-driven helix-helix transition in $\mathrm{CHCl}_{3} / \mathrm{DMF}$.

KEY WORDS: Dendritic Polymer / Glutamic Acid / Helical Polyacetylene /

Amino acids are constituents of proteins and peptides, and not only are biologically important but also are useful substances for chiral auxiliaries and building blocks in organic synthesis. ${ }^{1}$ Amino acid-based synthetic polymers are expected to show biocompatibility and biodegradability similarly to polypeptides. Among varieties of amino acid-based synthetic polymers, amino acid-substituted polyacetylenes have attracted much attention due to the ability to form regulated secondary structures and responsiveness to external stimuli. Poly(phenylacetylene) derivatives with amino acid pendants show liquid crystalline properties based on the helical structure. ${ }^{2,3}$ They also exhibit self-assembling properties, form superhelical fibers, and change the helical sense by medium. ${ }^{4-8}$ We have synthesized a series of amino acid-based poly( $N$-propargylamide)s $\mathrm{s}^{9-12}$ and poly(propargy ester)s $\mathrm{s}^{13}$ to find that they undergo helix inversion and/or transformation from a helix to a random coil according to external stimuli such as $\mathrm{pH},{ }^{14}$ heat, and solvent. ${ }^{15-17}$

On the other hand, dendrimers and dendritic polymers belong to a new class of macromolecules consisting of a cascade-branched structure. They gather interest due to their highly three-dimensional structure and a synthetic point of view. Recently, they are finding wide applications such as nanoscopic building blocks, catalysts, optoelectronic materials, and drug delivery systems. ${ }^{18}$ Dendronized helical poly(phenylacetylene)s form interesting architectures including ultra-high density arrays of helical wires, porous protein mimics, and exhibit permselectivity and self-healing. ${ }^{19}$ In this article, we report the synthesis and chiroptical properties of glutamic acid-based novel helical dendritic poly(phenylacetylene)s (Scheme 1).

\section{EXPERIMENTAL}

\author{
Measurements \\ ${ }^{1} \mathrm{H}(400 \mathrm{MHz})$ and ${ }^{13} \mathrm{C}(100 \mathrm{MHz})$ NMR spectra were \\ recorded on a JEOL EX-400 spectrometer. IR spectra were
}

measured on a JASCO FTIR-4100 spectrophotometer. Melting points $(\mathrm{mp})$ were measured on a YANACO micro melting point apparatus. High-resolution mass spectra were recorded on a JEOL JMS-HX110A and a JMS-SX102A spectrometers. Specific rotations $\left([\alpha]_{\mathrm{D}}\right)$ were measured on a JASCO DIP-1000 digital polarimeter with a sodium lamp as a light source. Number- and weigh-average molecular weights $\left(M_{\mathrm{n}}\right.$ and $\left.M_{\mathrm{w}}\right)$ of polymers were determined by gel permeation chromatography (GPC) on a JASCO Gulliver system (PU-980, CO-965, RI-930, and UV-1570) equipped with polystyrene gel columns (Shodex columns K804, K805, and J806), using tetrahydrofuran (THF) as an eluent calibrated by polystyrene standards at $40^{\circ} \mathrm{C}$. CD and UV-vis spectra were recorded on a JASCO $\mathrm{J}-820$ spectropolarimeter.

\section{Materials}

Solvents used for polymerization were purified by standard methods. 4-Ethynylbenzoic acid ${ }^{20}$ and the second generation L-glutamic acid-based dendritic peptide $\left(\right.$ Boc-G2) ${ }^{21}$ were synthesized according to the literature. All other reagents were purchased, and used without further purification.

\section{Synthesis of $N$-(4-Ethynylphenylcarbonyl) L-Glutamic Acid} Diethyl Ester (1)

4-Ethynylbenzoic acid $(1.2 \mathrm{~g}, 8.2 \mathrm{mmol})$, 4-(dimethylamino)pyridine (DMAP, $0.23 \mathrm{~g}, 1.8 \mathrm{mmol}$ ), and 1-(3-(dimethylamino)propyl)-3-ethylcarbodiimide hydrochloride ( $\mathrm{EDC} \cdot \mathrm{HCl}$, $1.70 \mathrm{~g}, 8.6 \mathrm{mmol}$ ) were subsequently added to a solution of $\mathrm{L}$ glutamic acid diethyl ester hydrochloride $(2.2 \mathrm{~g}, 9.2 \mathrm{mmol})$ and $\mathrm{Et}_{3} \mathrm{~N}(0.87 \mathrm{~g}, 8.6 \mathrm{mmol})$ dissolved in $\mathrm{CH}_{2} \mathrm{Cl}_{2}(50 \mathrm{~mL})$ at $0{ }^{\circ} \mathrm{C}$. After the resulting mixture was stirred at room temperature overnight, the reaction solution was washed with saturated sodium hydrogen carbonate aq., $10 \%$ citric acid aq., and water. The organic phase was dried over anhydrous $\mathrm{MgSO}_{4}$ and concentrated on a rotary evaporator. The crude product was purified by silica gel column chromatography eluted with $n$ hexane/AcOEt (1/3, v/v) to obtain $\mathbf{1}(2.0 \mathrm{~g}, 6 \mathrm{mmol})$ as a white

Department of Polymer Chemistry, Graduate School of Engineering, Kyoto University, Katsura Campus, Kyoto 615-8510, Japan

*To whom correspondence should be addressed (E-mail: sanda@adv.polym.kyoto-u.ac.jp, masuda@adv.polym.kyoto-u.ac.jp). 

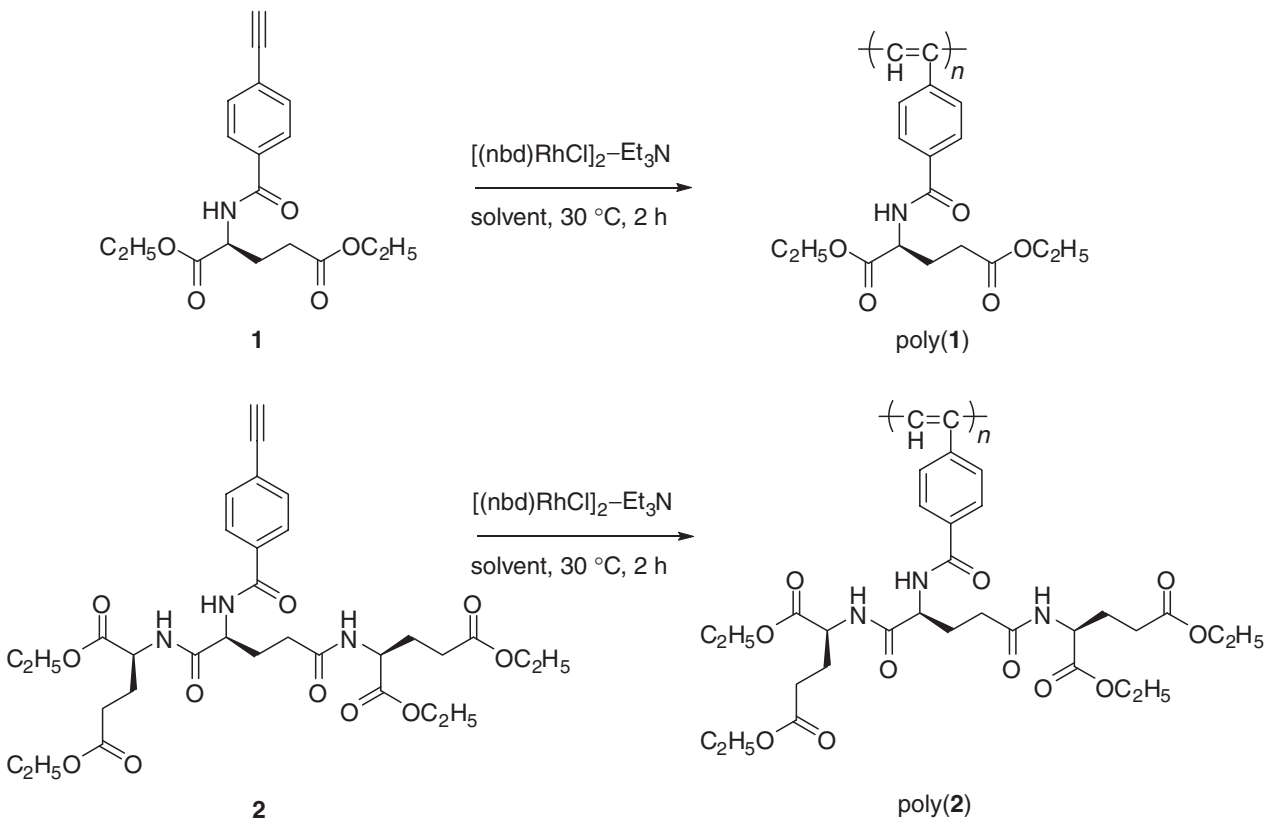

Scheme 1. Polymerization of monomers 1 and 2.

solid in $74 \%$ yield. Mp 68.0-69.0 ${ }^{\circ} \mathrm{C},[\alpha]_{\mathrm{D}}=+17^{\circ}(c=0.1 \mathrm{~g} /$ $\mathrm{dL}$, in $\left.\mathrm{CHCl}_{3}\right)$. IR $\left(\mathrm{KBr}, \mathrm{cm}^{-1}\right): 3322,2983,1732,1638,1524$, 1498, 1381, 1200, 1104, 1020, 857, 772, 651. ${ }^{1} \mathrm{H}$ NMR (400 $\left.\mathrm{MHz}, \mathrm{CDCl}_{3}\right): \delta 7.79(\mathrm{~d}, J=8.4 \mathrm{~Hz}, 2 \mathrm{H}, \mathrm{Ar}), 7.55(\mathrm{~d}, J=$ $8.4 \mathrm{~Hz}, 2 \mathrm{H}, \mathrm{Ar}), 7.11$ (d, $J=7.2 \mathrm{~Hz}, 1 \mathrm{H}, \mathrm{NH}), 4.58(\mathrm{~s}, 1 \mathrm{H}$, $\mathrm{NHCH}), 4.26\left(\mathrm{q}, J=7.2 \mathrm{~Hz}, 2 \mathrm{H}, \mathrm{COOCH}_{2}\right), 4.10$ (q, $J=$ $\left.7.2 \mathrm{~Hz}, 2 \mathrm{H}, \mathrm{COOCH}_{2}\right), 3.21(\mathrm{~s}, 1 \mathrm{H}, \mathrm{C} \equiv \mathrm{CH}), 2.12-2.54[\mathrm{~m}, 4 \mathrm{H}$, $\left.\mathrm{CO}\left(\mathrm{CH}_{2}\right)_{2}\right], 1.31\left(\mathrm{t}, J=7.2 \mathrm{~Hz}, 3 \mathrm{H}, \mathrm{CH}_{3}\right), 1.23(\mathrm{t}, J=7.2 \mathrm{~Hz}$, $\left.3 \mathrm{H}, \mathrm{CH}_{3}\right) .{ }^{13} \mathrm{C} \mathrm{NMR}\left(100 \mathrm{MHz}, \mathrm{CDCl}_{3}\right): \delta 173.3,171.8$ $\left(\mathrm{COOCH}_{2}\right), 166.2(\mathrm{CONH}), 133.6,132.3,127.1,125.6\left(\mathrm{C}_{6} \mathrm{H}_{4}\right)$, $82.7(C \equiv \mathrm{CH}), \quad 79.6(\mathrm{C} \equiv \mathrm{CH}), 61.8,60.8\left(\mathrm{COOCH}_{2}\right), \quad 52.5$ $(\mathrm{NHCH}), 30.5\left(\mathrm{CH}_{2} \mathrm{COO}\right), 27.0\left(\mathrm{CH}_{2} \mathrm{CH}_{2} \mathrm{COO}\right), 14.1\left(\mathrm{CH}_{3}\right)$. High-resolution mass. Calcd for $\mathrm{C}_{18} \mathrm{H}_{21} \mathrm{NO}_{5}$ : $[\mathrm{M}+1]^{+}$: 332.1398. Found: 332.1495.

\section{Synthesis of a Phenylacetylene Bearing an L-Glutamic Acid-based Dendritic Peptide (2)}

The title compound was synthesized from 4-ethynylbenzoic acid and Boc-G2 in a manner similar to monomer $\mathbf{1}$, of which $t$-butoxycarbonyl group was removed with trifluoroacetic acid prior to the reaction. ${ }^{21}$ The crude product was purified by silica gel column chromatography eluted with $\mathrm{CHCl}_{3} / \mathrm{MeOH}(95 / 5$, $\mathrm{v} / \mathrm{v})$ to obtain 2 as a white solid in $64 \%$ yield. Mp 160.0$161.5^{\circ} \mathrm{C},[\alpha]_{\mathrm{D}}=+10^{\circ}\left(c=0.1 \mathrm{~g} / \mathrm{dL}\right.$, in $\left.\mathrm{CHCl}_{3}\right)$. IR $(\mathrm{KBr}$, $\left.\mathrm{cm}^{-1}\right): 3288,2984,1732,1634,1538,1450,1381,1302,1209$, 1024, 855, 690. ${ }^{1} \mathrm{H} \mathrm{NMR}\left(400 \mathrm{MHz}, \mathrm{CDCl}_{3}\right): \delta 8.10(\mathrm{~d}$, $J=8.8 \mathrm{~Hz}, 1 \mathrm{H}, \mathrm{NH}), 7.75(\mathrm{~d}, J=8.4 \mathrm{~Hz}, 2 \mathrm{H}, \mathrm{Ar}), 7.59$ (d, $J=8.8 \mathrm{~Hz}, 1 \mathrm{H}, \mathrm{NH}), 7.52(\mathrm{~d}, J=8.4 \mathrm{~Hz}, 2 \mathrm{H}, \mathrm{Ar}), 7.06(\mathrm{~d}$, $J=8.8 \mathrm{~Hz}, 1 \mathrm{H}, \mathrm{NH}), 4.67(\mathrm{~m}, 2 \mathrm{H}, \mathrm{NHCH}), 4.52(\mathrm{~s}, 1 \mathrm{H}$, $\mathrm{NHCH}), 4.10-4.23\left(\mathrm{~m}, 8 \mathrm{H}, \mathrm{COOCH}_{2}\right), 3.20(\mathrm{~s}, 1 \mathrm{H}, \mathrm{C} \equiv \mathrm{CH})$, 1.99-2.47 (m, 12H, $\left.\mathrm{CH}_{2}\right), 1.20-1.32\left(\mathrm{~m}, 12 \mathrm{H}, \mathrm{CH}_{3}\right) .{ }^{13} \mathrm{C} \mathrm{NMR}$ $\left(100 \mathrm{MHz}, \mathrm{CDCl}_{3}\right): \delta 173.5,173.3,172.8,172.5,171.7$ $\left(\mathrm{COOCH}_{2}\right), 166.0(\mathrm{CONH}), 133.7,132.1,127.1,125.4\left(\mathrm{C}_{6} \mathrm{H}_{4}\right)$,
$82.8(\mathrm{C} \equiv \mathrm{CH}), 79.4(\mathrm{C} \equiv \mathrm{CH}), 62.2,62.0,60.7,60.6\left(\mathrm{COOCH}_{2}\right)$, 52.7, 51.8, $51.6(\mathrm{NHCH}), 32.2,30.6,30.3,28.9,26.8,26.7$ $\left(\mathrm{CH}_{2}\right.$ of $\left.\mathrm{Glu}\right), 14.1,14.0\left(\mathrm{CH}_{3}\right)$. High-resolution mass. Calcd for $\mathrm{C}_{18} \mathrm{H}_{21} \mathrm{NO}_{5}$ : $[\mathrm{M}+1]^{+}$: 646.2976. Found: 646.2976.

\section{Polymerization}

Polymerizations were carried out in a glass tube equipped with a three-way stopcock under dry nitrogen. [(nbd)RhCl $]_{2}$ and $\mathrm{Et}_{3} \mathrm{~N}$ were added to a monomer solution under nitrogen, and the resulting solution $\left([\mathrm{M}]_{0}=0.10 \mathrm{M},[\mathrm{Rh}]=1.0 \mathrm{mM}\right.$, $\left[\mathrm{Et}_{3} \mathrm{~N}\right]=10 \mathrm{mM}$ ) was kept at $30^{\circ} \mathrm{C}$ for $2 \mathrm{~h}$. Then, it was poured into a large mount of $n$-hexane to precipitated polymer. It was separated by filtration using a membrane filter (ADVANTEC H100A047A) and dried to constant weight under reduced pressure.

\section{RESULTS AND DISCUSSION}

\section{Monomer Synthesis and Polymerization}

L-Glutamic acid-based dendronized phenylacetylene monomers 1 and 2 were synthesized by the condensation of 4ethynylbenzoic acid with L-glutamic acid diethyl ester and an L-glutamic-based dendritic peptide using $\mathrm{EDC} \cdot \mathrm{HCl}$ and DMAP as condensation agents. The monomers were identified by ${ }^{1} \mathrm{H},{ }^{13} \mathrm{C} \mathrm{NMR}$, and IR spectroscopies as well as highresolution mass spectrometry.

Table I summarizes the polymerization of monomers $\mathbf{1}$ and 2 using $[\mathrm{Rh}(\mathrm{nbd}) \mathrm{Cl}]_{2}-\mathrm{Et}_{3} \mathrm{~N}$ as a catalyst. Polymers [poly(1) and poly(2)] with high molecular weights ranging from 422,000 to $1,470,000$ were obtained in $83-95 \%$ yields. They were soluble in $\mathrm{CHCl}_{3}, \mathrm{CH}_{2} \mathrm{Cl}_{2}$, THF, and DMF. In addition, poly(1) was soluble in $\mathrm{MeOH}$, while poly(2) was not. 
Table I. Polymerization of Monomers 1 and $\mathbf{2}^{\mathrm{a}}$

\begin{tabular}{|c|c|c|c|c|c|c|c|c|}
\hline \multirow{3}{*}{ Monomer } & \multirow{3}{*}{ Solvent } & \multicolumn{7}{|c|}{ Polymer } \\
\hline & & \multirow{2}{*}{$\begin{array}{c}\text { Yield }^{b} \\
(\%)\end{array}$} & \multirow{2}{*}{$M_{\mathrm{n}}{ }^{\mathrm{c}}$} & \multirow{2}{*}{$M_{\mathrm{w}} / M_{\mathrm{n}}{ }^{\mathrm{c}}$} & \multicolumn{4}{|c|}{$[\alpha]_{D}^{d}(\operatorname{deg})$} \\
\hline & & & & & $\mathrm{CHCl}_{3}$ & THF & $\mathrm{MeOH}$ & DMF \\
\hline 1 & $\mathrm{CHCl}_{3}$ & 95 & 422,000 & 1.57 & -740 & -111 & +243 & +308 \\
\hline 1 & $\mathrm{CH}_{2} \mathrm{Cl}_{2}$ & 93 & 698,000 & 1.41 & $-^{\mathrm{e}}$ & $-^{\mathrm{e}}$ & $-^{\mathrm{e}}$ & $-^{\mathrm{e}}$ \\
\hline 1 & THF & 91 & 993,000 & 1.58 & -669 & -119 & +267 & +319 \\
\hline 1 & Toluene & 93 & $1,470,000$ & 1.33 & - $^{\mathrm{e}}$ & $-^{e}$ & - $^{e}$ & $-^{\mathrm{e}}$ \\
\hline 2 & $\mathrm{CHCl}_{3}$ & 93 & 477,000 & 1.47 & -43 & -53 & $-^{f}$ & -74 \\
\hline 2 & $\mathrm{CH}_{2} \mathrm{Cl}_{2}$ & 84 & 674,000 & 1.52 & $-^{e}$ & $-^{e}$ & $-^{f}$ & - $^{\mathrm{e}}$ \\
\hline 2 & THF & 83 & 415,000 & 3.25 & -36 & -63 & $-^{f}$ & -76 \\
\hline
\end{tabular}

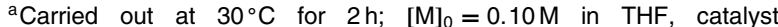
$[(\mathrm{nbd}) \mathrm{RhCl}]_{2}-\mathrm{Et}_{3} \mathrm{~N},[\mathrm{Rh}]=1.0 \mathrm{mM},\left[\mathrm{Et}_{3} \mathrm{~N}\right]=10 \mathrm{mM} .{ }^{\mathrm{b}} n$-Hexane-insoluble part. ' Determined by GPC (polystyrene, THF). ${ }^{\mathrm{d}}$ Measured by polarimetry at room temperature $(c=0.1 \mathrm{~g} / \mathrm{dL})$. $[\alpha]_{\mathrm{D}}$ of 1 and 2 measured in $\mathrm{CHCl}_{3}$ : $+17^{\circ}$ and $+10^{\circ}$ e Not measured. ${ }^{\mathrm{f}}$ Insoluble.

\section{Chiroptical Properties of the Polymers}

As listed in Table I, poly(1) showed minus specific rotations in $\mathrm{CHCl}_{3}$ and $\mathrm{THF}$, and positive ones in $\mathrm{MeOH}$ and $\mathrm{DMF}$, which were much larger than that of monomer $\mathbf{1}$. This strongly suggests that poly(1) forms a helical structure with predominantly one-handed screw sense in these solvents. On the other hand, poly(2) showed relatively small specific rotations in the solvents. We measured the $\mathrm{CD}$ and UV-vis spectra of the polymers to confirm the presence of a helical structure. As shown in Figure 1, poly(1) exhibited intense minus and plus $\mathrm{CD}$ signals at 370 and $320 \mathrm{~nm}$ in $\mathrm{CHCl}_{3}$, corresponding to the $\mathrm{UV}-\mathrm{vis}$ absorption assignable to the polyacetylene backbone. In DMF and $\mathrm{MeOH}$, poly(1) exhibited $\mathrm{CD}$ signals at the same wavelengths as those in $\mathrm{CHCl}_{3}$, but the signs were opposite, which agreed with the results of the specific rotations. Consequently, it was confirmed that poly(1) took a predom-

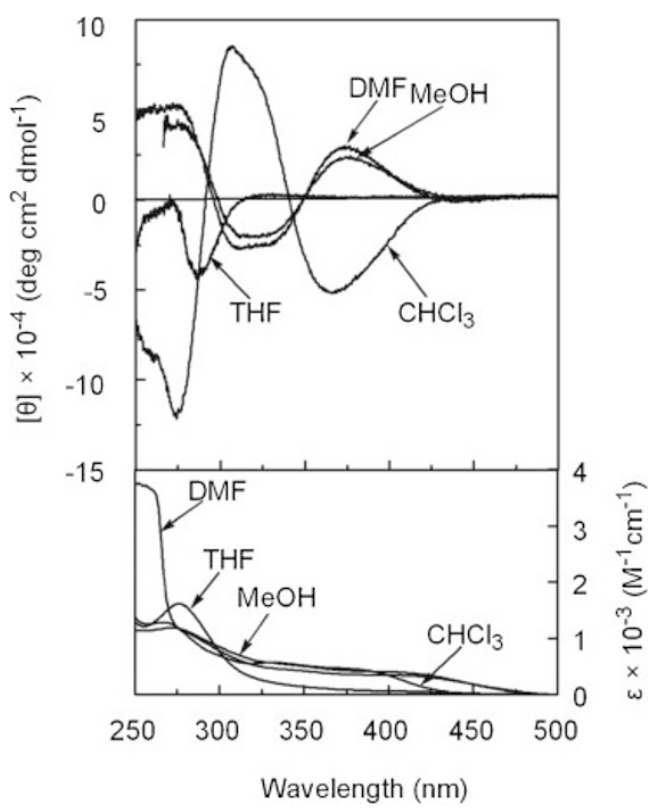

Figure 1. $C D$ and UV-vis spectra of poly(1) measured in various solvents $\left(c=1.0 \times 10^{-4} \mathrm{M}\right)$ at room temperature.
Table II. IR Spectroscopic Data (Amide $\mathrm{C}=\mathrm{O}$ Absorption) of the Monomers and Polymers

\begin{tabular}{ccc}
\hline \multirow{2}{*}{ Compound } & \multicolumn{2}{c}{ Wavenumber $\left(\mathrm{cm}^{-1}\right)$} \\
\cline { 2 - 3 } & Solution State $^{\mathrm{a}}$ & Solid State $^{\mathrm{b}}$ \\
\hline $\mathbf{1}$ & 1665 & 1638 \\
Poly(1) & 1638 & 1638 \\
$\mathbf{2}$ & 1667 & $-^{\mathrm{c}}$ \\
Poly(2) & 1654 & C $^{\mathrm{c}}$
\end{tabular}

a Measured in $\mathrm{CHCl}_{3}(c=20 \mathrm{mM}) .{ }^{\mathrm{b}} \mathrm{KBr}$ pellet. ${ }^{\mathrm{c}}$ Not clear.

inantly one-handed helical structure in these solvents, and the predominant helical sense in $\mathrm{CHCl}_{3}$ was opposite to that in DMF and $\mathrm{MeOH}$. In THF, poly(1) exhibited a $\mathrm{CD}$ pattern different from those of $\mathrm{CHCl}_{3}, \mathrm{DMF}$, and $\mathrm{MeOH}$. The helix seems tight in THF compared with that in the other three solvents judging from the UV-vis spectra, because largely twisted helical polyacetylenes have a shorter conjugation length than loosely twisted ones. ${ }^{22}$ THF has the highest donor ability among the solvents, so it may interact with the polymer differently from the other ones, leading to the $\mathrm{CD}$ spectroscopic difference. However, detailed explanation of the solvent effect is difficult as commonly recognized.

The helical conformation of amino acid-based $\operatorname{poly}(\mathrm{N}$ propargylamdie)s ${ }^{14,16}$ and poly(phenylacetylene) $\mathrm{s}^{7,8}$ is stabilized by intramolecular hydrogen bonding between the amide groups at the side chains as well as steric repulsion. The present polymers are also possibly the case. We measured the solidand solution-state IR spectra of the monomers and polymers to check the presence of hydrogen bonding in the polymers. As shown in Table II, there was no difference between the amide $v_{\mathrm{C}=\mathrm{O}}$ peaks of $\mathbf{1}$ and poly(1) in solid state. On the other hand, poly(1) showed the amide absorption peak at $1638 \mathrm{~cm}^{-1}$ in $\mathrm{CHCl}_{3}$, which was $27 \mathrm{~cm}^{-1}$ lower than that of $\mathbf{1}$. Judging from the low compound concentration $(c=20 \mathrm{mM})$, it is concluded that poly(1) forms intramolecular hydrogen bonding between the amide groups. $\operatorname{Poly}(2)$ also seems to form intramolecular hydrogen bonding between the amide groups, but less efficiently than $\operatorname{poly}(\mathbf{1})$ because the $v_{\mathrm{C}=\mathrm{O}}$ wavenumbers of poly(2) are higher than those of poly(1) both in solution and solid states. It is likely that the largely dendritic structure of poly(2) is unfavorable to the efficient formation of hydrogen bonding.

\section{Temperature- and Solvent-Induced Conformational Change}

As described above, poly(1) formed intramolecular hydrogen bonding, presumably contributing to the stabilization of the helical structure in a manner similar to previously reported amino acid-based poly( $N$-propargylamide)s. ${ }^{10}$ If this assumption is operative, the helical structure should be sensitive to external stimuli such as heat and solvent. Figure 2 depicts the temperature dependence of CD and UV-vis spectra of poly(1) measured in $\mathrm{CHCl}_{3}$ and DMF. Poly(1) slightly reduced the intensity of the $\mathrm{CD}$ signal around $370 \mathrm{~nm}$ in $\mathrm{CHCl}_{3}$, and largely in DMF with raising temperature. On the other hand, the UV- 

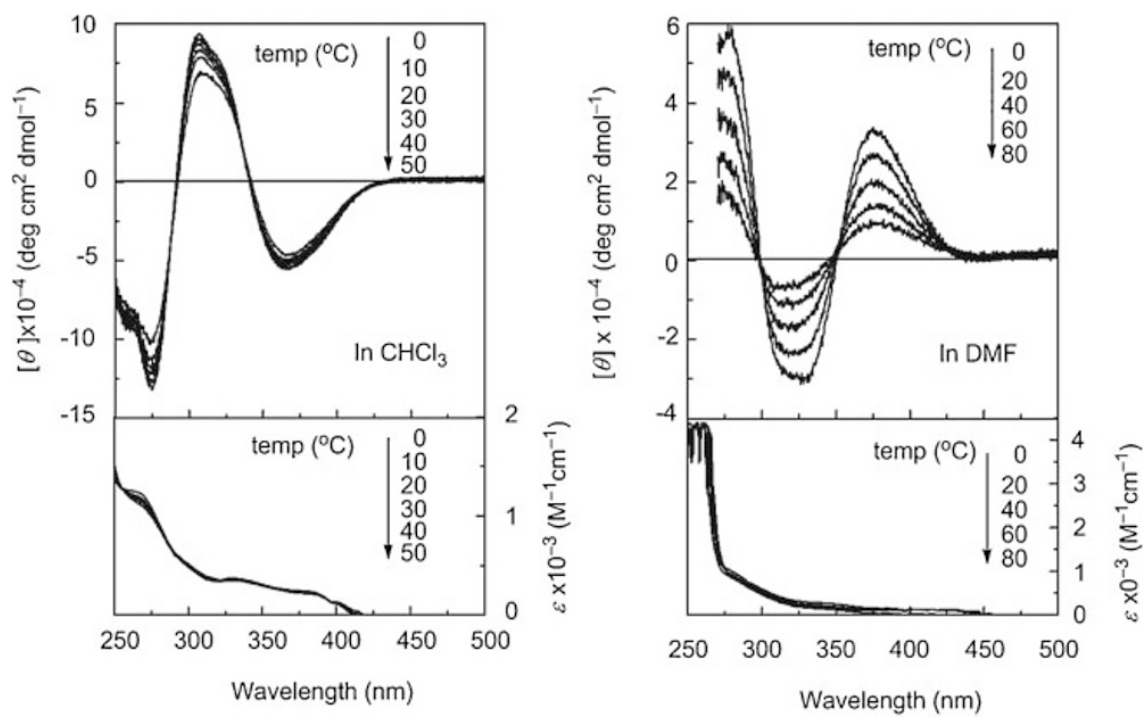

Figure 2. $\mathrm{CD}$ and UV-vis spectra of poly(1) measured in $\mathrm{CHCl}_{3}$ and in $\mathrm{DMF}\left(c=1.0 \times 10^{-4} \mathrm{M}\right)$ at various temperatures.

vis spectra were almost the same irrespective of temperature. This fact leads to the conclusion that the decrease in the CD signal is not caused by transition from a helix to a random state but by depopulation of the helical conformation. The helical conformation of poly(1) was thermally more stable in $\mathrm{CHCl}_{3}$ than in DMF, presumably due to no hydrogen-bonding interaction between poly(1) and $\mathrm{CHCl}_{3}$. In $\mathrm{DMF}$, the amide moieties of poly(1) possibly form intermolecular hydrogen bonding with the solvent, which disturbs the formation of regulated intramolecular hydrogen bonding between the amide groups, resulting in the higher sensitivity.

As shown in Figure 3, poly(2) exhibited a CD and UV-vis spectroscopic change upon heating more largely than poly(1) in

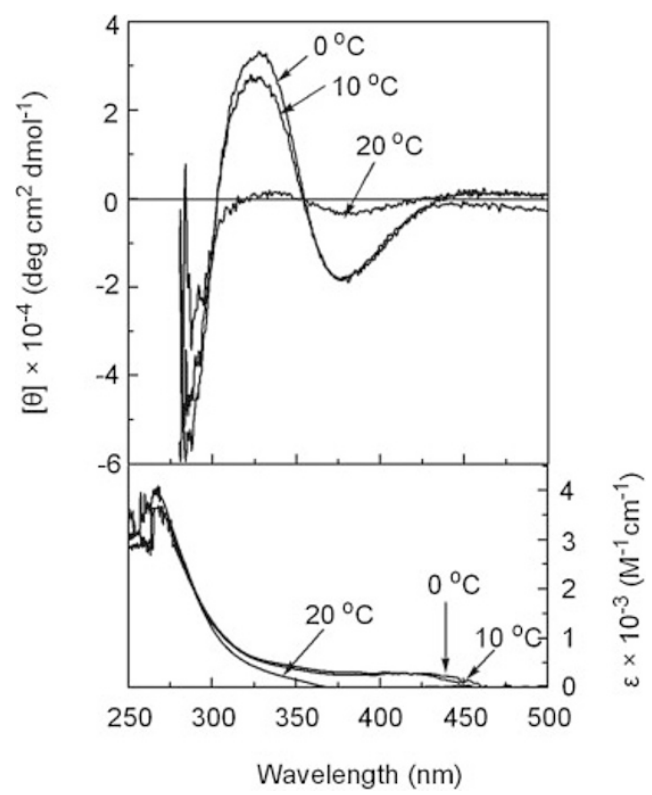

Figure 3. $C D$ and UV-vis spectra of poly(2) measured in DMF $(c=1.0 \times$ $\left.10^{-4} \mathrm{M}\right)$ at various temperatures.
DMF. The CD signals of poly(2) almost disappeared at $20^{\circ} \mathrm{C}$ At this temperature, the UV-vis absorption at $375-460 \mathrm{~nm}$ also disappeared. It seems that poly(2) underwent transformation from a helix to a random coil as well as helix inversion. This instability of the helical structure of poly(2) seems to be caused by the less efficient intramolecular hydrogen bonding than that of poly(1). We have reported the relationship between the position of a chiral center and secondary structure of substituted polyacetylenes, ${ }^{23}$ in which polymers bearing a chiral center away from the backbone do not form a helix. Judging from the result, it is likely that the chiral center closest to the main chain of poly(2) predominantly determines the helical sense. Poly(2) exhibited specific rotations and CD intensities smaller than those of $\operatorname{poly}(\mathbf{1})$, indicating that the one-handedness of helical structure of $\operatorname{poly}(2)$ is less than that of poly(1). The chiral centers of poly(2) may compete each other to decrease one-handed helicity.

As described above, $\operatorname{poly}(\mathbf{1})$ forms helices with the opposite screw sense in $\mathrm{CHCl}_{3}$ and DMF, and the helix is thermally more stable in $\mathrm{CHCl}_{3}$ than in DMF. It is therefore expected that the helix sense is inverted by changing the composition of $\mathrm{CHCl}_{3}$ and DMF. As shown in Figure 4, poly(1) exhibited minus and plus $C D$ signals at 370 and $320 \mathrm{~nm}$ in $\mathrm{CHCl}_{3}$. It gradually decreased the signal intensities with increase of the DMF content, and turned the signs into plus and minus ones, respectively, when the DMF content reached $25 \%$. The intensities of the $\mathrm{CD}$ signals gradually increased by further increase of the DMF content. This CD spectroscopic change clearly indicates that poly(1) inverted the helical sense depending on the composition of $\mathrm{CHCl}_{3}$ and DMF.

\section{CONCLUSION}

In this article, we have synthesized novel chiral dendritic L-glutamic acid-based poly(phenylacetylene)s [poly(1) and 


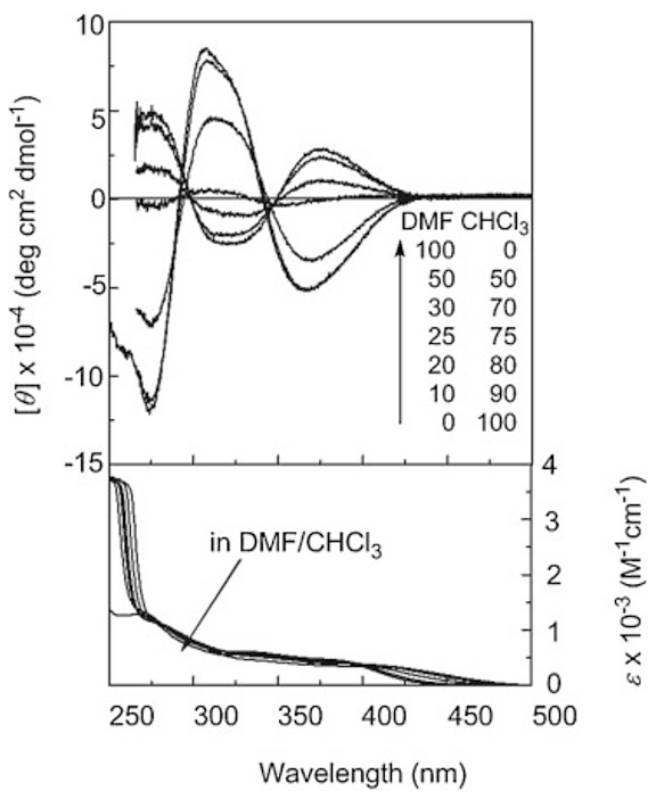

Figure 4. $\mathrm{CD}$ and UV-vis spectra of poly(1) measured in $\mathrm{CHCl}_{3} / \mathrm{DMF}$ $\left(c=1.0 \times 10^{-4} \mathrm{M}\right)$ with various compositions.

poly(2)] with high molecular weights. The intense CD signal and large specific rotation indicated the polymers formed a helical structure with predominantly one-handed screw sense. Poly(1) formed intramolecular hydrogen bonding between the amide groups more efficiently than $\operatorname{poly}(2)$ did, leading to the higher stability of the helical structure to heat. $\operatorname{Poly}(\mathbf{1})$ inverted the helical sense depending on the composition of $\mathrm{CHCl}_{3}$ and DMF.

Received: October 4, 2007 Accepted: November 1, 2007 Published: December 11, 2007

\section{REFERENCES}

1. F. Sanda and T. Endo, Macromol. Chem. Phys., 200, 2651 (1999).

2. K. Okoshi, K. Sakajiri, J. Kumaki, and E. Yashima, Macromolecules, 38, 4061 (2005).

3. K. Okoshi, S. Sakurai, S. Ohsawa, and E. Yashima, Angew. Chem., Int. Ed., 45, 8173 (2006).

4. B. S. Li, K. K. L. Cheuk, F. Salhi, J. W. Y. Lam, J. A. K. Cha, X. Xiao, C. Bai, and B. Z. Tang, Nano Lett., 1, 323 (2001).

5. K. K. L. Cheuk, J. W. Y. Lam, J. Chen, L. M. Lai, and B. Z. Tang, Macromolecules, 36, 5947 (2003).

6. K. K. L. Cheuk, J. W. Y. Lam, L. M. Lai, Y. P. Dong, and B. Z. Tang, Macromolecules, 36, 9752 (2003).

7. B. S. Li, S. Z. Kang, K. K. L. Cheuk, W. J. Li, L. Ling, C. Bai, and B. Z. Tang, Langmuir, 20, 7598 (2004).

8. L. M. Lai, J. W. Y. Lam, and B. Z. Tang, J. Polym. Sci., Part A: Polym. Chem., 44, 2117 (2006).

9. G. Gao, F. Sanda, and T. Masuda, Macromolecules, 36, 3932 (2003).

10. H. Zhao, F. Sanda, and T. Masuda, Polymer, 46, 2841 (2005).

11. F. Sanda, H. Araki, and T. Masuda, Macromolecules, 38, 10605 (2005).

12. H. Zhao, F. Sanda, and T. Masuda, Macromol. Chem. Phys., 206, 1653 (2005).

13. F. Sanda, H. Araki, and T. Masuda, Macromolecules, 37, 8510 (2004).

14. F. Sanda, K. Terada, and T. Masuda, Macromolecules, 38, 8149 (2005).

15. G. Gao, F. Sanda, and T. Masuda, Macromolecules, 36, 3938 (2003).

16. H. Zhao, F. Sanda, and T. Masuda, Macromolecules, 37, 8888 (2004).

17. H. Zhao, F. Sanda, and T. Masuda, Macromolecules, 37, 8893 (2004).

18. H. Frauenrath, Prog. Polym. Sci., 30, 325 (2005).

19. J. G. Rudick and V. Percec, New J. Chem., 31, 1083 (2007).

20. J. M. Njus, D. J. Sandman, L. Yang, and B. M. Foxman, Macromolecules, 38, 7645 (2005).

21. F. E. Appoh, D. S. Thomas, and H. B. Kraatz, Macromolecules, 38, 7562 (2005).

22. V. Percec, M. Obata, J. G. Rudick, B. B. De, M. Glodde, T. K. Bera, S. N. Magonov, V. S. K. Balagurusamy, and P. A. Heiney, J. Polym. Sci., Part A: Polym. Chem., 40, 3509 (2002).

23. J. Tabei, M. Shiotsuki, F. Sanda, and T. Masuda, Macromolecules, 38, 5860 (2005). 